\title{
Ethanolic Extracts of the Gongronema latifolium Stem and Leaves Caused Mild Renal Injury and Modulated Serum Triglycerides in Rats
}

\author{
Faoziyat A Sulaiman 1,*(D), Babalola O Yusuf ${ }^{1}$, Sikemi A Omar ${ }^{1}$, Hamdalat F Muritala ${ }^{1}$, Jimoh M \\ Adisa $^{2}$, Azeezat A Olopade ${ }^{1}$, Faith I Babajamu ${ }^{1}$, Aminat T Jimba ${ }^{1}$, Adenike L Babatunde ${ }^{1}$, Bashirat A \\ Adeniyi ${ }^{1}$, Bukola R Opaleye ${ }^{1}$, Rotdelmwa F Maimako ${ }^{3, *}$ (D), David A Otohinoyi ${ }^{4}{ }^{\mathbb{D}}$, Kabir O Bello ${ }^{1}$, \\ Damilare Rotimi $^{3}$ (i) , Omorefosa O Osemwegie ${ }^{5 \text { (i) }}$, Oluyomi S Adeyemi ${ }^{3}, *$ (D)
}

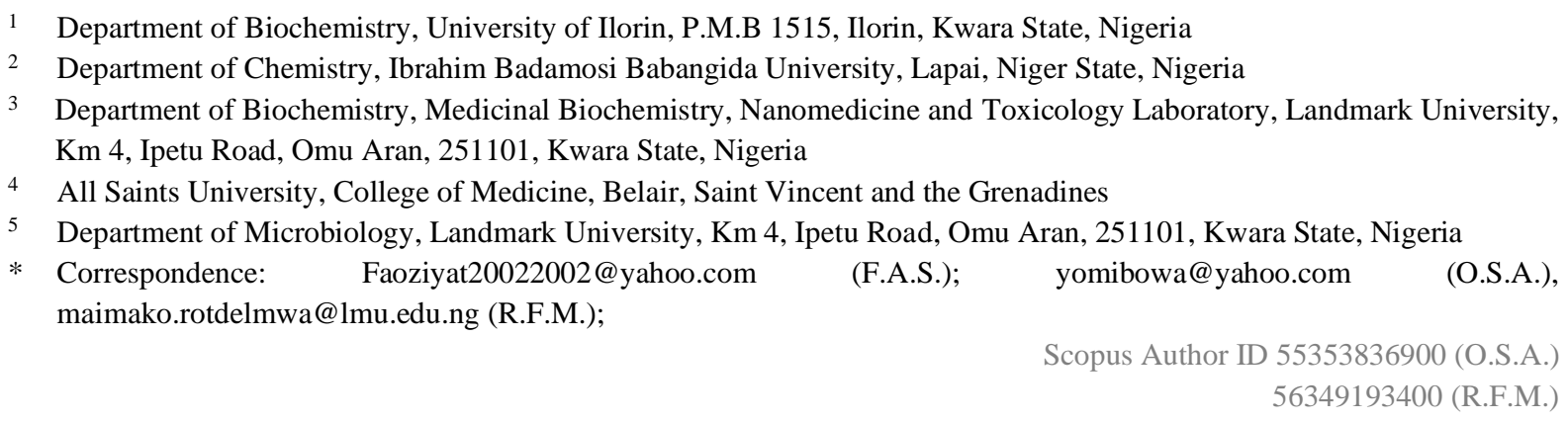

Received: 23.07.2021; Revised: 5.09.2021; Accepted: 10.09.2021; Published: 17.10.2021

\begin{abstract}
Gongronema latifolium is a tropical plant with verse traditionally and medicinal uses in mostly Africa and Asia. In this work, we determined the biochemical effects of G. latifolium ethanolic extracts in male Wistar rats. The G. latifolium stem and leaves were air-dried separately, macerated, and extracted in $80 \%$ ethanol. The Wistar rats were assigned into three groups randomly; control was administered distilled water, the treatment groups respectively were given $200 \mathrm{mg} / \mathrm{kg}$ bw of the extracts of leaves or stem for twenty-eight (28) days. Data showed that the rat serum ALT and ALP activities were lower in the extract-treated group than in the control group administered distilled water. In the rat liver, there were significant differences $(p<0.05)$ in biochemical parameters compared to the control group as the extract-treated group showed a reduction in ALT, AST, and ALP activities. Meanwhile, the oral administration of the G. latifolium extracts led to the elevated $(p<0.05)$ level of serum urea, while the serum triglycerides and creatinine levels were reduced compared with the control. Together, the data suggest that G. latifolium extracts at the doses tested had minimal renal toxicity.
\end{abstract}

Keywords: biochemical toxicology; medicinal biochemistry; natural products; drug discovery.

(C) 2021 by the authors. This article is an open-access article distributed under the terms and conditions of the Creative Commons Attribution (CC BY) license (https://creativecommons.org/licenses/by/4.0/).

\section{Introduction}

Gongronema latifolium, also known as the Amaranth globe, is native to the tropics and is readily found in West Africa. The plant is of the family Asclepiadaceae and belongs to the genus Gongronema [1-3]. The G. latifolium is edible, and when consumed fresh, it gives a sensational taste that is sour and mildly pleasant [4-7]. Additionally, G. latifolium is acclaimed not only to be nutritious but medicinal [8]. For example, G. latifolium is richly nutritive with many lipids, proteins, amino acids (essential and non-essential), vitamins, and mineral elements [8-11]. Also, the dry matter of G. latifolium has been shown to contain tangible levels of essential fatty acids such as linoleic acids [12]. Linoleic acid is a precursor to arachidonic acid, 
and it forms a significant part of the membrane phospholipids [12]. Furthermore, G. latifolium leaves have been implicated in possessing mineral elements such as sodium, calcium, potassium, iron, and magnesium [11].

The G. latifolium is used for medicinal purposes [13, 14]; traditionally, the plant infusion and/or decoction is applied to treat digestive challenges such as indigestion, abdominal ache, lack of bowel movement, diarrhea as well as intestinal parasites [9, 10]. Additionally, the G. latifolium is part of the decoction usually applied to help detoxify and restore the liver in hepatitis patients [15]. In separate reports, the $G$. latifolium has been used to treat hyperglycemia and hypertension, hepatitis and alcohol-induced liver damage [16], as well as womb cleansing and abdominal pain after childbirth [10]. The leaves used in cooking have also been potent in relieving cold and loss of appetite [17]. In the present investigation, the biochemical toxicity of the extracts of the G. latifolium was determined in male Wistar rats. This is to ascertain the safety of its consumption and usage in alternative medicine. This will further serve as a guideline to the consumption and usage of G. latifolium.

\section{Materials and Methods}

\subsection{Assay kit for the metabolites and enzyme assay.}

Assays of alkaline phosphatase (ALP), alanine aminotransferase (ALT), aspartate aminotransferase (AST), creatine, triglycerides, cholesterol, bilirubin, albumin, and urea were performed using reagent kits gotten commercially (Randox Laboratories Limited, Crumlin, UK).

\subsection{Extract preparation from Gongonema latifolium.}

The fresh whole plant part of Gongonema (stem and leaves) were collected respectively from the Flower garden and Sanrab within the Ilorin metropolis of Kwara state in Nigeria. The plant was validly identified with a voucher number UILH/001/855 at the Herbarium unit of the Plant Biology department, University of Ilorin, Nigeria. The stem and leaves of the Gongronema were washed and air-dried. After that, the plant leaves and stem were pulverized and extracted with $80 \%$ ethanol for $72 \mathrm{~h}$ at $4{ }^{\circ} \mathrm{C}$. The extracts were filtered using a muslin cloth and concentrated using a rotary evaporator (Buchi Rotavapor - R110) at reduced pressure at $55^{\circ} \mathrm{C}$.

\subsection{Experimental animals.}

Nine (9) male Wistar rats of average weight $110 \pm 35 \mathrm{~g}$ were obtained from the animal unit of the Department of Biochemistry, University of Ilorin, Nigeria. The male rats were identified through physical observations and were used to avoid the hormonal interactions caused by the estrus cycle in females. The Wistar male rats were accommodated in wellventilated plastic cages with sawdust as beddings and kept in standard laboratory conditions (12-hour light and dark cycle, $25 \pm 2^{\circ} \mathrm{C}$ ). The rats were sustained on standard rat pellets, and they were given unrestricted access to clean water. The handling of rats was under the guidance of the Laboratory Animal Ethics Committee of the University of Ilorin. This was consistent with the NIH guide for the care and use of laboratory animals [18]. The rats were acclimated for two weeks before the experimental treatments commenced. 


\subsection{Experimental grouping and treatments.}

The rats were grouped randomly into three (3) rats per group. The control group was given distilled water only, while the treatment groups respectively received either the ethanolic extracts of G. latifolium stem or leaves $(0.4 \mathrm{mg} / \mathrm{kg} \mathrm{bw})$ re-suspended in distilled water. The treatments were daily and orally administered for twenty-eight days.

\subsection{Necroscopy.}

After the last treatment, the rats were sacrificed after an overnight fast using anaesthetization mildly with diethyl ether. Blood samples were then collected into sterile bottles by incising the jugular vein, while the vital organs such as liver, heart, and kidney were then excised, weighed, and homogenized in isotonic sucrose solution $(0.25 \mathrm{M})$. The homogenates were stored frozen at $-4{ }^{\circ} \mathrm{C}$ until used for biochemical assays.

After $30 \mathrm{~min}$ at room temperature, the blood samples were centrifuged for $10 \mathrm{~min}$ at $1000 \mathrm{~g}$ (Uniscope Model SM800B, England, UK). The supernatant was collected using Pasteur's pipette and stored frozen at $-4{ }^{\circ} \mathrm{C}$ until used for the biochemical assays.

\subsection{Biochemical assay.}

The determination of the rat serum and total tissue protein (TP), albumin, AST, ALT, ALP, bilirubin, urea, creatinine, and triglycerides were carried out by using commercial assay kits (Randox, Crumlin, UK).

\subsection{Statistical analysis.}

The data obtained were analyzed using a one-way analysis of variance (ANOVA) on SPSS (IBM, USA). Duncan Multiple Range test was applied for the posthoc analyses, and the results are presented as mean \pm standard error of the mean (SEM, while mean values at $p<0.05$ are significant.

\section{Results and Discussion}

The percentage yield of G. latifolium ethanolic extracts was $11.97 \%$ for the leaves and $9.61 \%$ for the stem. Meanwhile, the oral administration of the ethanolic extracts caused no weight change in the average rat weight and the organ to rat weight ratio after 28 days of administration (Figures 1-3).

The rat liver AST activity in ethanolic extract-treated groups decreased when compared with control (Figure 4). The rat serum and heart AST levels were elevated compared with control. However, the rat tissue and serum ALT levels in treated groups had no appreciable changes compared with control (Figure 5). Conversely, the rat kidney, heart, and serum ALP levels in rats treated with ethanolic extracts of $G$. latifolium leaves were increased when compared with control (Figure 6). The levels of rat serum urea increased $(p<0.05)$ when in comparison with the control. However, the serum's bilirubin, creatinine, and albumin levels had no appreciable change compared with the control (Figure 7). Additionally, the oral administration of the ethanolic extracts of $G$. latifolium caused a reduction $(p<0.05)$ in rat serum triglycerides. 


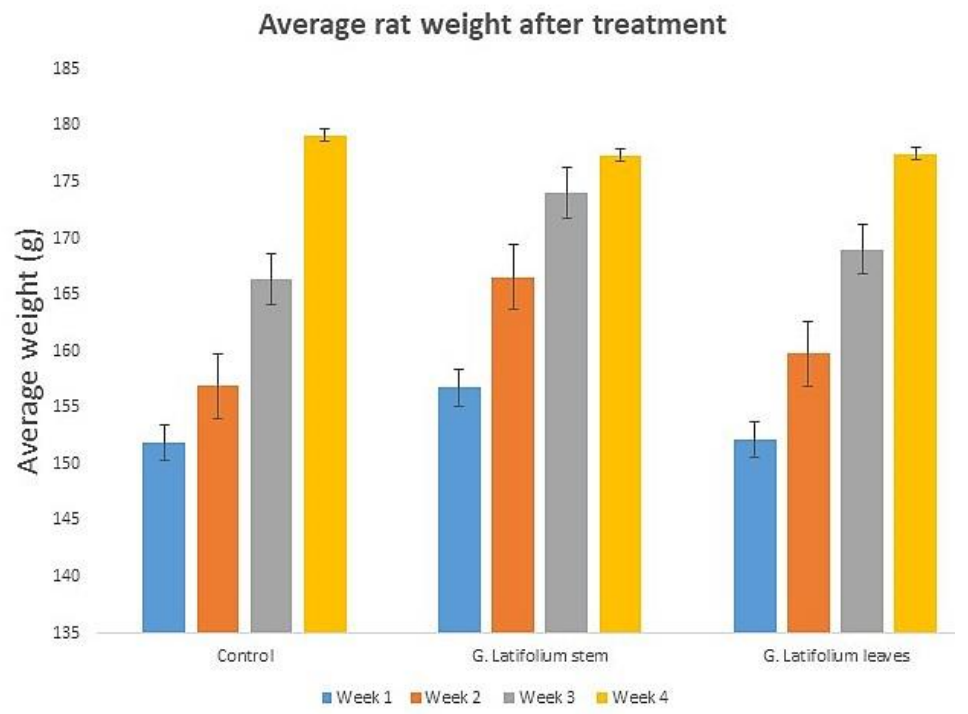

Figure 1. The average weight of the rats after oral administration of the ethanolic extracts of Gongronema latifolium. Data are mean of three replicates \pm standard error of the mean (SEM).

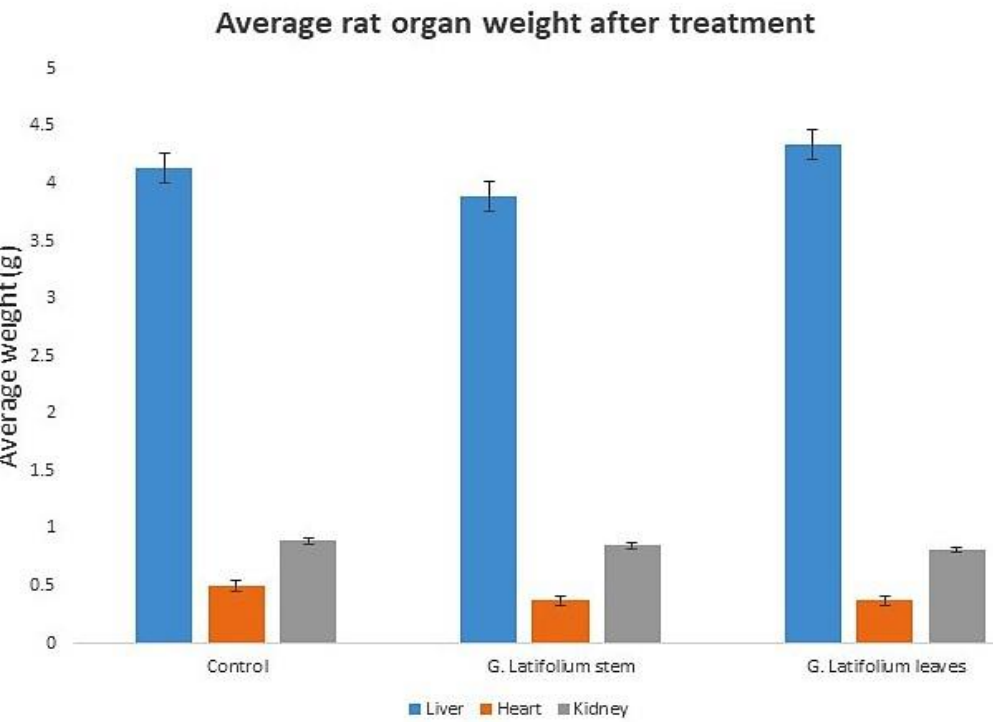

Figure 2. Average weight of rat organs after oral administration of the ethanolic extracts of Gongronema latifolium. Data are mean of three replicates \pm standard error of the mean (SEM).

Rat organ-body weight ratio after treatment

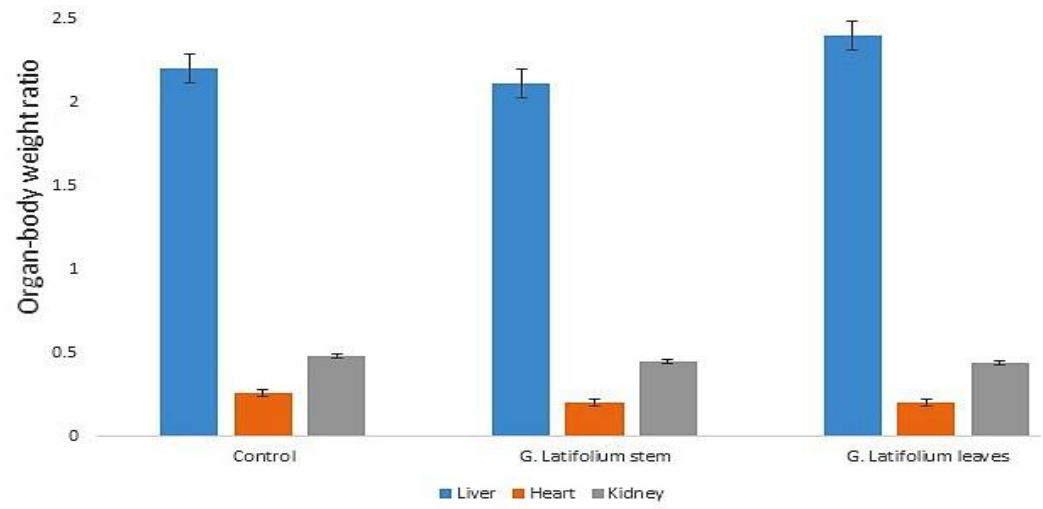

Figure 3. Rat organ to body weight ratio after oral administration of the ethanolic extracts of Gongronema latifolium. Data are mean of three replicates \pm standard error of the mean (SEM). 


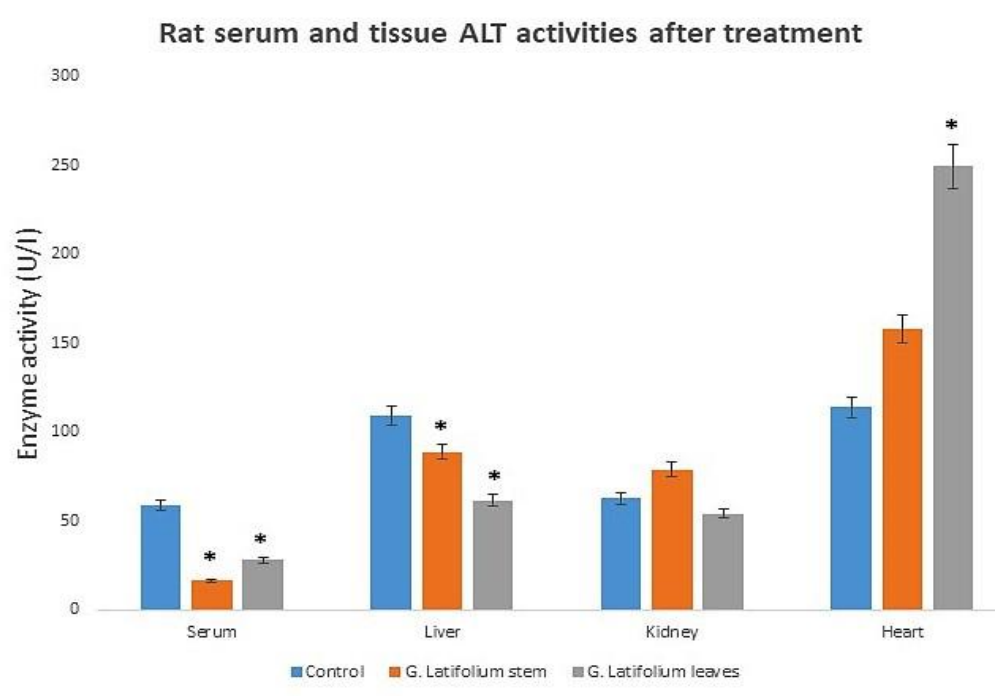

Figure 4. Aspartate transaminase (AST) activities (U/I) in rat serum, liver, kidney, and heart after oral administration of the ethanolic extracts of Gongronema Latifolium. Data are mean of three replicates \pm standard error of the mean (SEM). * is significant at $\mathrm{p}<0.05$ versus the control.

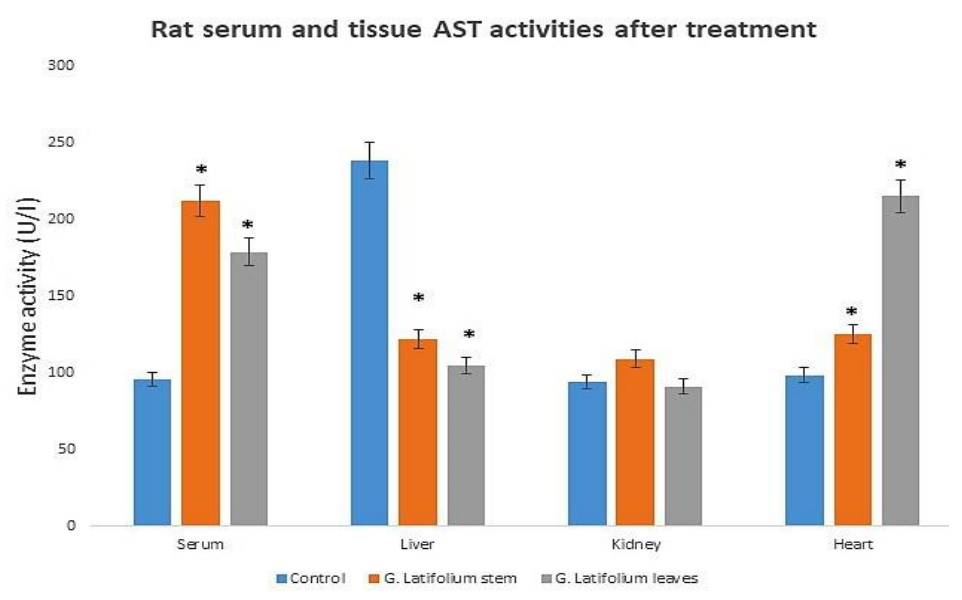

Figure 5. Alanine transaminase (ALT) activities (U/I) in rat serum, liver, kidney, and heart after oral administration of the ethanolic extracts of Gongronema Latifolium. Data are mean of three replicates \pm standard error of the mean (SEM). * is significant at $\mathrm{p}<0.05$ versus the control.

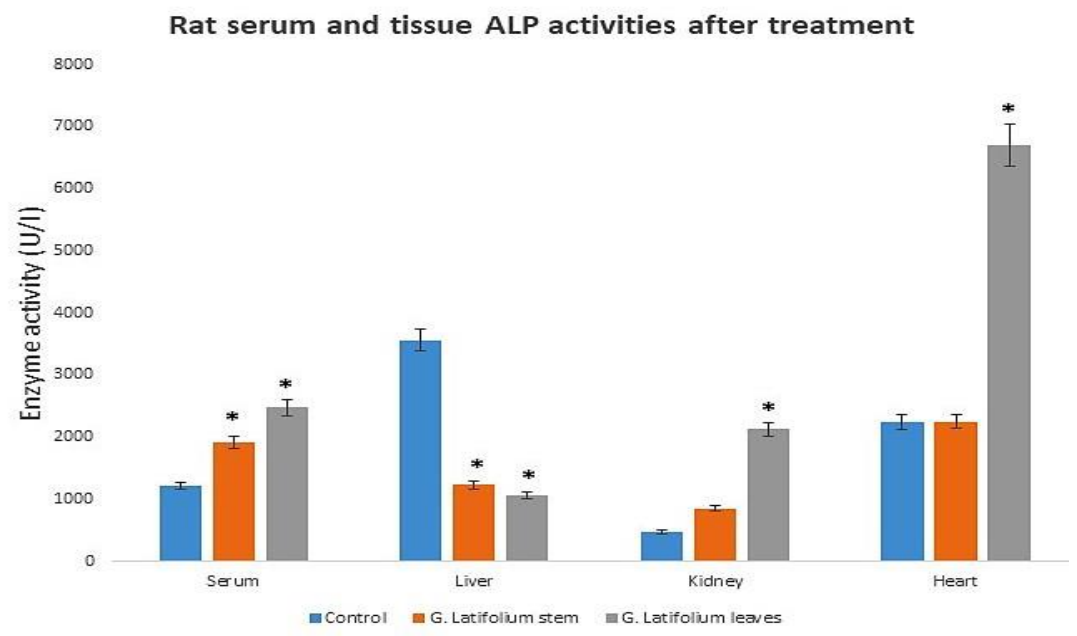

Figure 6. Alkaline phosphatase (ALP) activities (U/I) in rat serum, liver, kidney, and heart after oral administration of the ethanolic extracts of Gongronema Latifolium. Data are mean of three replicates \pm standard error of the mean (SEM). * is significant at $\mathrm{p}<0.05$ versus the control. 


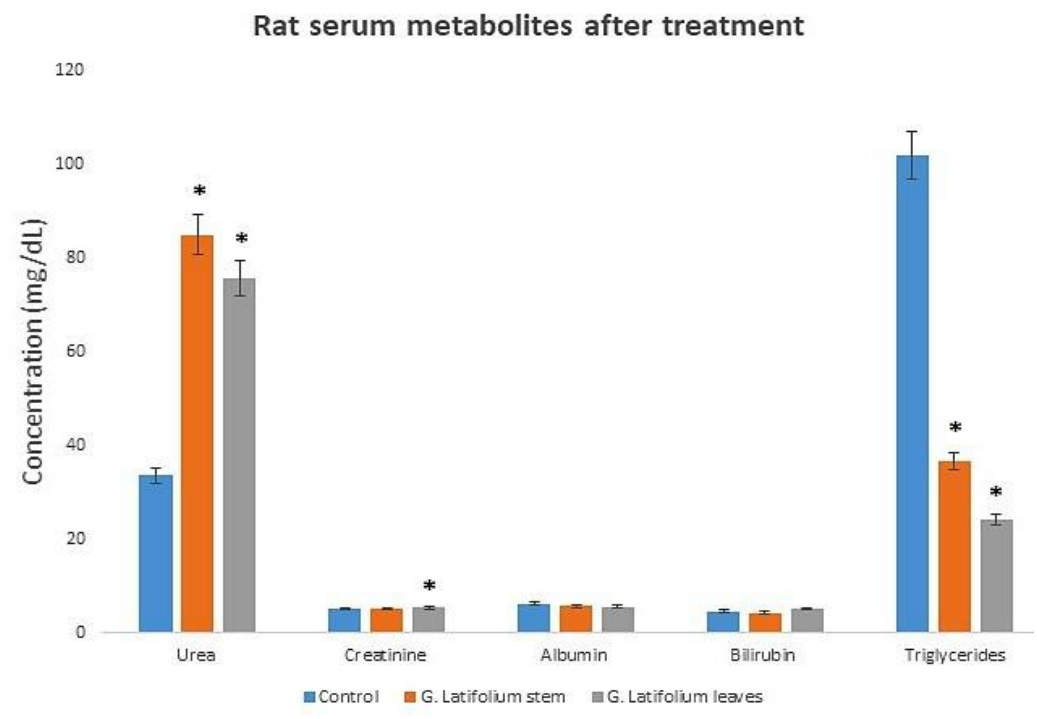

Figure 7. Biochemical indices in serum of rats after oral administration of the ethanolic extracts of Gongronema latifolium. Data are mean of three replicates \pm standard error of the mean (SEM). * is significant at $p<0.05$ versus the control.

\subsection{Discussion.}

Numerous recent investigations have been seeking possible ways to harness natural products as alternative treatment strategies, especially from plants with a proven traditional history of medicinal value [19-23]. The G. Latifolium, is a perennial plant used for domestic and medicinal purposes, predominantly in eastern Asia and West Africa [24, 25]. With its popular and common usage in these regions, the need to profile the plant for safety and/or toxicity is imperative. In this present work, we determined the biochemical toxicity of $G$. latifolium in Wistar rats. Data showed that the ethanolic extracts of G. Latifolium leaf and stem did not cause alterations in the rat body and organ weights compared to control. This finding seems to agree with previous studies showing the nutritional value of G. Latifolium [12]. The evaluation for rat liver toxicity showed that the ethanolic extracts of G. Latifolium leaves and stem did not cause hepatotoxicity; liver function indices such as ALT and AST have not elevated appreciably compared with control. Additionally, rat serum bilirubin and albumin levels were comparable to those of the control, suggesting the absence of hepatic assault. However, the reduced levels of AST, ALT, and ALP activities after oral exposure to the ethanolic extracts of G. latifolium might be due to the potential of the extract or its metabolite to inhibit the activities of these enzymes. Conversely, an increase in rat heart AST, ALP, and ALT levels may denote the potential of $G$. Latifolium to predispose to cardiovascular perturbations [26, 27].

Furthermore, we determined rat serum urea and creatinine levels to ascertain kidney function. The ethanolic extracts increased rat serum urea levels compared with control. The increase in serum urea levels might indicate the ensuing impairment of kidney function $[28,29]$. Previously, reports demonstrated the hepato-renal toxicities of G. latifolium in rats [23]. The decreased triglyceride level in rat serum might be due to the gastric emptying effect of G. Latifolium, as was previously shown elsewhere [30]. Also, G. Latifolium has been reported to contain niacin, which may interfere with lipid metabolism by inhibiting hormonesensitive lipase and prevent hepatic VLDL synthesis, thus decreasing triglycerides and LDL while increasing HDL levels [31-35]. 


\section{Conclusions}

In conclusion, our findings suggest that the administration of ethanolic extracts of $G$. Latifolium might not have caused liver injury at the doses investigated. Conversely, the ethanolic extracts caused mild renal disturbances as reflected in an elevated serum urea level. Additionally, the reduction in the rat serum triglyceride level by the ethanolic extracts may indicate a potential benefit for cardiovascular functioning.

\section{Funding}

This research received no external funding.

\section{Acknowledgments}

The authors acknowledge the laboratory staff of the Department of Biochemistry, University of Ilorin, Nigeria.

\section{Conflicts of Interest}

The authors declare no conflict of interest.

\section{References}

1. Okafor, J.C.; Okolo, H.C.; Ejiofor, M.A.N. Strategies for enhancement of utilization potential of edible woody forest species of south-eastern Nigeria. In: The Biodiversity of African Plants: Proceedings XIVth AETFAT Congress 22-27 August 1994, Wageningen, The Netherlands. van der Maesen, L.J.G.; van der Burgt, X.M.; van Medenbach de Rooy, J.M. Eds.; Springer Netherlands: Dordrecht, 1996; pp. 684-695, https://doi.org/10.1007/978-94-009-0285-5_84.

2. Akani, N.P.; Nwachukwu, C.; Hakam, I.O. Evaluation of the Antibacterial Activity of Gongronema latifolium and Costus afer Leaf Extracts on E. coli (ATCC 29455) and S. aureus (ATCC 25923). International Journal of Pathogen Research 2020, 11-16, https://doi.org/10.9734/IJPR/2020/v5i430139.

3. Obroh, A.A.; Oshim, I.O.; Odeyemi, O.; Urama, E.U.; Olise, N.A. Demonstration of the Minimum Inhibitory Concentration (Mic) and Minimal Bactericidal Concentration (Mbc) of Both Moringa oleifera and Gongronema latifolium Extracts Mixture against Staphylococcus aureus, Salmonella typhi and Escherichia coli. Journal of Advances in Medical and Pharmaceutical Sciences 2021, 46-52, https://doi.org/10.9734/jamps/2021/v23i130216.

4. Memariani, Z.; Farzaei, M.H.; Ali, A.; Momtaz, S. Chapter Seven-Nutritional and bioactive characterization of unexplored food rich in phytonutrients. In: Phytonutrients in Food. Nabavi, S.M.; Suntar, I.; Barreca, D.; Khan, H. Eds.; Woodhead Publishing: 2020; pp. 157-175, https://doi.org/10.1016/B978-0-12-8153543.00001-0.

5. Chukwudozie, I.K.; Agbo, M.C.; Ugwu, K.O.; Ezeonu, I.M. Oral Administration of Gongronema lafifoliumLeaf Extract Modulates Gut Microflora and Blood Glucose of Induced Diabetic Rats. J Pure Appl Microbiol 2021, 15, 346-355, https://doi.org/10.22207/JPAM.15.1.29.

6. Antia, B.; Ita, B.; Akpan, I. Nutritional evaluation and antioxidant activity of a lesser-known wild edible fruit Tristemma hirtum. P. Beauv. 2020, https://doi.org/10.7176/JNSR/10-6-08.

7. Aisida, S.O.; Ugwu, K.; Akpa, P.A.; Nwanya, A.C.; Ejikeme, P.M.; Botha, S.; Ahmad, I.; Maaza, M.; Ezema, F.I. Biogenic synthesis and antibacterial activity of controlled silver nanoparticles using an extract of Gongronema Latifolium. Materials Chemistry and Physics 2019, 237, https://doi.org/10.1016/j.matchemphys.2019.121859.

8. Ogunyemi, O.M.; Gyebi, A.G.; Adebayo, J.O.; Oguntola, J.A.; Olaiya, C.O. Marsectohexol and other pregnane phytochemicals derived from Gongronema latifolium as $\alpha$-amylase and $\alpha$-glucosidase inhibitors: in vitro and molecular docking studies. SN Applied Sciences 2020, 2, 1-11, https://doi.org/10.1007/s42452-02003951-0.

9. Adeleye, I.A.; Omadime, M.E.; Daniels, F.V. Antimicrobial activity of essential oil and extracts of Gongronema latifolium Decne on bacterial isolates from blood stream of HIV infected patients. Journal of Pharmacology and Toxicology 2011, 6, 312-320, https://doi.org/10.3923/jpt.2011.312.320.

10. Agbo, C.U.; Baiyeri, K.P.; Obi, I.U. Indigenous knowledge and utilization of Gongronema latifolia Benth.: A case study of women in University of Nigeria, Nsukka. Bio-research 2005, 3, 66-69, https://doi.org/10.4314/br.v3i2.28596. 
11. Eleyinmi, A.F. Chemical composition and antibacterial activity of Gongronema latifolium. Journal of Zhejiang University Science B 2007, 8, 352-358, https://doi.org/10.1631/jzus.2007.B0352.

12. Glew, R.S.; VanderJagt, D.J.; Huang, Y.S.; Chuang, L.T.; Bosse, R.; Glew, R.H. Nutritional analysis of the edible pit of Sclerocarya birrea in the Republic of Niger (daniya, Hausa). Journal of Food Composition and Analysis 2004, 17, 99-111, https://doi.org/10.1016/S0889-1575(03)00101-7.

13. Beshel, J.A.; Palacios, J.; Beshel, F.N.; Nku, C.O.; Owu, D.U.; Nwokocha, M.; Bórquez, J.; Simirgiotis, M.J.; Nwokocha, C.R. Blood pressure-reducing activity of Gongronema latifolium Benth.(Apocynaeceae) and the identification of its main phytochemicals by UHPLC Q-Orbitrap mass spectrometry. Journal of basic and clinical physiology and pharmacology 2020, 31, https://doi.org/10.1515/jbcpp-2018-0178.

14. Aralu, C.C.; Chukwuemeka-Okorie, H.O.; Akpomie, K.G. Inhibition and adsorption potentials of mild steel corrosion using methanol extract of Gongronema latifoliuim. Applied Water Science 2021, 11, 1-7, https://doi.org/10.1007/s13201-020-01351-8.

15. Ihesie, G. The Guardian Newspaper. www.ngrguardiannews.com./2015/09/health benefits of Gongronema latifolium-utazi. 2015 Retrieved on 30th October, 2015.

16. Ugochukwu, N.H.; Babady, N.E. Antihyperglycemic effect of aqueous and ethanolic extracts of Gongronema latifolium leaves on glucose and glycogen metabolism in livers of normal and streptozotocin-induced diabetic rats. Life Sciences 2003, 73, 1925-1938, https://doi.org/10.1016/S0024-3205(03)00543-5.

17. Okorie, H.M.; Obeagu, E.I.; Okpoli, H.C.; Omoviye, E.O. The Effect of Gongronema Latifolum (Utazi) on Some Haematological Parameters of Rabbit. J Cardiol Cardiovas Res 2020, 1, 1-9.

18. National Research Council. Guide for the Care and Use of Laboratory Animals. 8th Ed. National Academies Science Press, 2011; 161-169.

19. Adeyemi, O.S.; Akanji, M.A. Biochemical changes in the kidney and liver of rats following administration of ethanolic extract of Psidium guajava leaves. Human \& Experimental Toxicology 2010, 30, 1266-1274, https://doi.org/10.1177/0960327110388534.

20. Adeyemi, O.S.; Akanji, M.A.; Ekanem, J.T. Ethanolic extract of Psidium guajava influences protein and bilirubin levels in Trypanosoma brucei brucei infected rats. J Biol Sci 2012, 12, 111-116, https://doi.org/10.3923/jbs.2012.111.116.

21. Adeyemi, O.S.; Fambegbe, M.; Daniyan, O.R.; Nwajei, I. Yoyo Bitters, a polyherbal formulation influenced some biochemical parameters in Wistar rats. Journal of Basic and Clinical Physiology and Pharmacology 2012, 23, 135-138, https://doi.org/10.1515/jbcpp-2012-0026.

22. Fabiyi, O.A.; Atolani, O.; Adeyemi, O.S.; Olatunji, G.A. Antioxidant and Cytotoxicity of $\beta$-Amyrin acetate fraction from Bridelia ferruginea Leaves. Asian Pacific Journal of Tropical Biomedicine 2012, 2, S981-S984, https://doi.org/10.1016/S2221-1691(12)60347-5.

23. Holy, B.; Davies, T.; Imomoemi, T.N. Hepato-renal toxicity of Gongronema latifolium extracts on streptozocin induced diabetes in rats. American Journal of Health Research 2016, 4, https://doi.org/10.11648/j.ajhr.20160403.15.

24. Omodamiro, O.D.; Alaebo, P.O.; Olukotun, B.G.; Chikezie, P.C. Evaluation of hepatotoxicity effect of methanol leave extract of Gongronema latifolium in Albino rats. World 2021, 1, 015-023, https://doi.org/10.53346/wjapls.2021.1.1.0017.

25. Akani, N.; Nwachukwu, C.; Hakam, I. Evaluation of the Antibacterial Activity of Gongronema latifolium and Costus afer Leaf Extracts on E. coli (ATCC 29455) and S. aureus (ATCC 25923). International Journal of Pathogen Research 2020, 11-16, https://doi.org/10.9734/IJPR/2020/v5i430139.

26. Schindhelm, R.K.; Dekker, J.M.; Nijpels, G.; Bouter, L.M.; Stehouwer, C.D.A.; Heine, R.J.; Diamant, M. Alanine aminotransferase predicts coronary heart disease events: A 10-year follow-up of the Hoorn Study. Atherosclerosis 2007, 191, 391-396, https://doi.org/10.1016/j.atherosclerosis.2006.04.006.

27. van Deursen, V.M.; Damman, K.; Hillege, H.L.; van Beek, A.P.; van Veldhuisen, D.J.; Voors, A.A. Abnormal Liver Function in Relation to Hemodynamic Profile in Heart Failure Patients. Journal of Cardiac Failure 2010, 16, 84-90, https://doi.org/10.1016/j.cardfail.2009.08.002.

28. Adeyemi, O.S.; Akanji, M.A. Psidium guajava leaf extract: effects on rat serum homeostasis and tissue morphology. Comparative Clinical Pathology 2012, 21, 401-407, https://doi.org/10.1007/s00580-010-11062 .

29. Adeyemi, O.S.; Sulaiman, F.A. Biochemical and morphological changes in Trypanosoma brucei bruceiinfected rats treated with homidium chloride and diminazene aceturate. Journal of basic and clinical physiology and pharmacology 2012, 23, 179-183, https://doi.org/10.1515/jbcpp-2012-0018.

30. Ogbu, S.O.; Agwu, K.K.; Asuzu, I.U. Gongronema latifolium delays gastric emptying of semi-solid meals in diabetic dogs. African Journal of Traditional, Complementary and Alternative Medicines 2013, 10, 325-331 https://doi.org/10.4314/ajtcam.v10i5.17.

31. Kamanna, V.S.; Ganji, S.H.; Kashyap, M.L. Recent advances in niacin and lipid metabolism. Current Opinion in Lipidology 2013, 24, 239-245, https://doi.org/10.1097/MOL.0b013e3283613a68.

32. Shibabaw, T. Omega-3 polyunsaturated fatty acids: anti-inflammatory and anti-hypertriglyceridemia mechanisms in cardiovascular disease. Molecular and Cellular Biochemistry 2021, 476, 993-1003, https://doi.org/10.1007/s11010-020-03965-7. 
33. Bahiru, E.; Hsiao, R.; Phillipson, D.; Watson, K.E. Mechanisms and Treatment of Dyslipidemia in Diabetes. Current Cardiology Reports 2021, 23, 1-6, https://doi.org/10.1007/s11886-021-01455-w.

34. Nguyen, N.T.; Nath, P.V.; Mai, V.Q.; Shakir, M.K.M.; Hoang, T.D. Treatment of Severe Hypertriglyceridemia During Pregnancy With High Doses of Omega-3 Fatty Acid and Plasmapheresis. AACE Clinical Case Reports 2021, 7, 211-215, https://doi.org/10.1016/j.aace.2021.01.006.

35. Bugarski, M.; Ghazi, S.; Polesel, M.; Martins, J.R.; Hall, A.M. Changes in NAD and Lipid Metabolism Drive Acidosis-Induced Acute Kidney Injury. Journal of the American Society of Nephrology 2021, 32, 342-356, https://doi.org/10.1681/ASN.2020071003. 